\title{
Born in Belo Horizonte: the trajectory of parturient women and their reproductive outcomes
}

\author{
Nascer em Belo Horizonte: a trajetória das parturientes e seus desfechos reprodutivos \\ Nacer en Belo Horizonte: la trayectoria de las parturientes y sus resultados reproductivos
}

How to cite this article:

Amorim T, Felisbino-Mendes MS, Schreck RSC, Ribeiro SP, Rezende EM, Martins EF. Born in Belo Horizonte: the trajectory of parturient women and their reproductive outcomes. Rev Esc Enferm USP. 2019;53:e03441. DOI: http://dx.doi.org/10.1590/S1980-220X2018000903441

\author{
Torcata Amorim ${ }^{1}$ \\ Mariana Santos Felisbino-Mendes ${ }^{1}$ \\ Rafaela Siqueira Costa Schreck ${ }^{1}$ \\ Sabrina Paiva Ribeiro ${ }^{2}$ \\ Edna Maria Rezende ${ }^{1}$ \\ Eunice Francisca Martins ${ }^{1}$ \\ ${ }^{1}$ Universidade Federal de Minas Gerais, Escola \\ de Enfermagem, Programa de Pós-Graduação \\ em Enfermagem, Belo Horizonte, MG, Brazil \\ ${ }^{2}$ Universidade Federal de Minas Gerais, \\ Escola de Enfermagem, Programa de \\ Residência em Enfermagem Obstétrica, \\ Belo Horizonte, MG, Brazil.
}

\begin{abstract}
Objective: To analyze the trajectory taken by pregnant women for delivery care in Belo Horizonte and its relation with the reproductive outcomes. Method: A cross-sectional study using a database from a study conducted in Belo Horizonte. The studied variables were referent to the trajectory of women seeking delivery care, to their social, demographic and health care characteristics, and to the reproductive outcomes. Odds Ratios were estimated with their 95\% confidence intervals to evaluate the factors associated with unfavorable trajectory and outcomes. Results: A total of 1,087 cases were studied, of which $39.3 \%$ had an unfavorable trajectory. The chance of having an unfavorable trajectory was higher for women who were not Belo Horizonte residents, with lower education, non-white race/color, and who had undergone prenatal care in public healthcare service. The prevalence of reproductive outcomes was similar regardless of the trajectory status, except for vaginal delivery. Conclusion: An unfavorable trajectory remains high, and shows weaknesses in the health care services network to guarantee timely and qualified access to pregnant women. However, the care received in the health services outweighs the risks of an unfavorable trajectory.
\end{abstract}

\section{DESCRIPTORS}

Pregnant Women; Parturition; Health Services Accessibility; Health Evaluation; Obstetric Nursing. 


\section{INTRODUCTION}

In the last decades, public policies and health actions for women and children have been prioritized in Brazil leading to advances, especially in reducing maternal and child mortality ${ }^{(1)}$. An important milestone in 2011 was the creation of the Rede Cegonha within the Unified Health System (SUS - Sistema UUnico de Saúde), which proposes a health care network to ensure women's right to reproductive planning and humanized care from pregnancy to puerperium. Among the objectives of this proposal is organization of the Health Care Network to guarantee access, reception and resolution, in order to reduce maternal and infant mortality and promoting the implementation of a new model of obstetric and perinatal care based on good practices, security and respect for human rights ${ }^{(2)}$.

Thus, the Rede Cegonha reinforces the right of the pregnant woman to knowledge and linkage to a maternity hospital as a reference for childbirth still in prenatal care, a guarantee of Law No.11.634, sanctioned since $2007^{(3)}$. It should be noted that this guarantee of reference and care continuity has been identified by the World Health Organization as an important strategy to improve the quality and access to maternal and child health services ${ }^{(4)}$.

However, even with this legal guarantee of reference and almost universal coverage for maternity hospitals in Brazil, there remains difficulty for pregnant women to access health facilities, especially due to the lack of integration between prenatal care and childbirth ${ }^{(1)}$. In 2012, this difficulty of access in the country was $16.2 \%$ according to data from the study "Birth in Brazil: survey on delivery and birth"(5). Regional differences were observed, and the problem was identified in one third of adolescent parturient mothers in the Northeast ${ }^{(6)}$, and in $12.8 \%$ of the total of southeastern women $^{(7)}$. In addition, the care network for pregnant women has been fragmented and has little resolution regarding the responsibilities of health services in the country ${ }^{(5,8)}$.

The literature points out that the main reasons for parturient women seeking care outside their home are especially the lack of obstetric and neonatal beds, the desire of the woman herself, including those seeking care in the private network, the absence of at-risk birth care in the municipality, and the demands for specialized care ${ }^{(8-10)}$.

The trajectory taken by pregnant women is usually marked by worries, suffering and uncertainties, which increases the risk of maternal and perinatal complications and deaths, since care can be provided late ${ }^{(9,11)}$. Findings from a study in Sudan pointed out that initial access to an ineffective service, especially in obstetric and neonatal emergency situations, slows down effective care and worsens obstetric outcomes compared to service unavailability ${ }^{(12)}$. In Brazil, national data indicate that the risk of neonatal death was five times higher in situations of when the pregnant woman has to commute to receive care in relation to those who obtained direct care ${ }^{(5)}$. In Belo Horizonte, a study on perinatal mortality indicated that about $15.0 \%$ of mortality cases occurred due to the difficulty for the pregnant woman to access the maternity unit, as well as failures in the care process ${ }^{(13)}$.
Since 2000, the Perinatal Commission of the municipality of Belo Horizonte has established a care flow for pregnant women and newborns based on the "Linking map of pregnant women from the Health Centers to Maternities of the Unified Health System (SUS)". This strategy organized services at increasing levels of complexity and delimited geographical areas of coverage for the population to be attended ${ }^{(14)}$. In the situation where it is impossible hospitalize, the reference maternity unit must evaluate and guarantee safe transportation to another maternity hospital after identifying a vacancy by means of the Internment Center of the municipality. This strategy also helps the professionals in the linking and precise orientation of pregnant women in the care network ${ }^{(14)}$.

Considering the efforts to create strategies, investments and construction of care flows for obstetric and neonatal care in Belo Horizonte, it is important to evaluate the situation of pregnant women's commute in the network. Despite the established mechanisms, their commute may be a remaining problem since the municipality is also a reference for the metropolitan region through the Pactual and Integrated Program $^{(15)}$ among managers. However, many situations are addressed beyond the Pact, or even the pregnant woman seeks out the service on her own initiative considering the proximity or ease of access, better quality of care and the fact that maternity units have an "open door" policy. This situation can overwhelm local maternities and make it difficult to provide care in the first service attended, and added to this is a lack of information on the trajectory of pregnant women for obstetric care in the state of Minas Gerais.

Thus, this study aims to analyze the trajectory taken by pregnant women for health care delivery in Belo Horizonte, the factors related to unfavorable trajectory and their reproductive outcomes. The results obtained could contribute to better understanding of the situation, and thus help to form public policies in order to guarantee better access to safe birth.

\section{METHOD}

\section{STUdY DESIGN}

A cross-sectional study.

\section{Population}

This study used data from the research "Born in Belo Horizonte: inquiry on delivery and birth". This hospitalbased survey was conducted from November 2011 to March 2013 in 11 maternity hospitals in the city of Belo Horizonte. All live births, regardless of weight and gestational age, and stillborn children weighing more than 500 grams and gestational age greater than 22 weeks were included. Exclusion criteria were postpartum women with severe mental disorders, foreigners who did not understand Portuguese, or deaf/ mute women. The sample was calculated considering the number of births of each institution, and the data collection was performed continuously in each maternity unit until the sample was completed. One case for this study was also excluded in which the woman did not declare her address of residence, totaling 1,087 puerperal women. 


\section{Data Collection}

The study adopted the same criteria as the "National Study: Survey on Delivery and Birth in Brazil"(16). A questionnaire applied to puerperal women was used as the instrument for data collection after at least 6 hours after delivery, and a second questionnaire was filled in from the records of the woman's and the newborn's medical records after hospital discharge of both. The maternal questionnaire consisted of questions on sociodemographic data, health plan, health conditions, obstetric history, prenatal care, admission to the hospital, labor, delivery, postpartum and information about the baby. Information on hospitalization, care for labor, delivery and newborns was found on the hospital chart, in addition to obstetric and perinatal outcomes. The interviews were conducted by trained nurses, data recorded on netbooks and then exported to an exclusive server.

\section{DATA ANALYSIS AND PROCESSING}

The following variables were included to investigate the trajectory of the parturient: care in another hospital before hospitalization (yes, no); municipality of women's residence (Belo Horizonte, another); time spent getting to the maternity hospital (in minutes); type of transportation used (car, bus, other); childbirth in the reference maternity unit (yes, no); reasons for delivery outside the reference maternity hospital (distance or difficult access, absence of vacancies, others) and for non-hospitalization in the previously attended maternity unit (absence of vacancies, lack of professionals, others). Seeking care in another maternity unit before isolated hospitalization, the municipality of the woman's origin was more than $50 \mathrm{~km}$ from Belo Horizonte, time of more than 1 hour to reach the maternity unit, and delivery not performed at the reference maternity hospital were all considered as an unfavorable trajectory.

The other variables of interest were sociodemographic characteristics: age, education, race/color, companion presence and economic class category; while the characteristics of obstetric care included prenatal and local performance, number of consultations and counseling regarding reference maternity unit; and reproductive outcomes were intercurrences in labor and delivery, type of delivery, fetal or neonatal death, resuscitation in the delivery room, neonatal ICU admission, and prematurity.

The trajectory of pregnant women was initially analyzed according to their origin, and the prevalence of unfavorable trajectory according to sociodemographic factors and characteristics related to obstetric care received was calculated. Odds Ratios (OR) were then estimated with their 95\% confidence intervals $(95 \% \mathrm{CI})$ to evaluate possible factors associated with the unfavorable trajectory through logistic regression. Finally, the same method was used to estimate the $\mathrm{OR}$ and $95 \% \mathrm{CI}$ of the occurrence of negative reproductive outcomes in the presence of unfavorable trajectory. The level of statistical significance of $5 \%$ was considered in all analyzes. The data obtained were analyzed using the Statistical Package for the Social Sciences for Windows Student Version (SPSS), version 18.0.

\section{ETHICAL ASPECTS}

The research project was approved by the Ethics Committee of the Federal University of Minas Gerais (UFMG), protocol CAAE - 0246.0.203.000-11, according to Resolution 466/12 of the Ministry of Health, and authorized by the leaders of participating maternity hospitals. All the puerperal women signed the free and Informed Consent Form (ICF), and had their identities preserved.

\section{RESULTS}

The majority of the studied cases came from the municipality of Belo Horizonte $(672=61.8 \%)$. The distance for non-resident women in Belo Horizonte was up to $50 \mathrm{~km}$ for $85.3 \%$ of them, and the longest distance traveled was $725 \mathrm{~km}$ (data not shown).

The time taken to reach maternity hospital was up to 30 minutes for most of the pregnant women living in Belo Horizonte, and 30 to 60 minutes for those who were not residents. The most used transport for access to the maternity unit was a private car, but non-resident pregnant women in Belo Horizonte more often used an ambulance. More than $80.0 \%$ of the residents in Belo Horizonte and $63.7 \%$ of the residents in other municipalities had their birth in the reference maternity unit. About $15.0 \%$ of the residents of Belo Horizonte and more than double the number of women residing in other municipalities received care in another hospital before admission. Likewise, the trajectory of these pregnant women was considered unfavorable for $27.5 \%$ of the women of Belo Horizonte and $58.3 \%$ of the non-residents. All these differences were statistically significant (Table 1).

Table 2 presents the reasons reported by puerperal women for non-delivery in the reference maternity unit and for care in another hospital before admission to delivery. The main reasons for not delivering in the reference maternity unit were: being distant or difficult to access, not liking the service, and a lack of vacancy, with no differences for residents and non-residents of Belo Horizonte. In relation to seeking more than one service for hospitalization, the main reason was the lack of vacancy, followed by not being in labor for women of Belo Horizonte, and the lack of on-call doctor for those non-residents.

It was observed that those women with primary and secondary education in relation to those with higher education, of different race/color from white, or of $\mathrm{C}, \mathrm{D}$ or $\mathrm{E}$ socioeconomic classes $(p<0.05)$ had a higher probability of having an unfavorable trajectory. No differences were observed according to age or marital status (Table 3).

It was also observed that almost all the women had prenatal consultations (99.3\%), most of them seven or more visits (89.6\%), performed in the public service (58.7\%) and also reported having received guidance regarding the reference maternity unit $(71.4 \%)$ (data not shown). In relation to these characteristics of obstetric care, the prevalence of unfavorable trajectory was similar ( $p>0.05$ ), except for the place of prenatal care, since women who underwent prenatal care in the public service were twice more likely to have an unfavorable trajectory compared to those provided care in the private service (Table 4). 
Table 1 - Trajectory of pregnant women to give birth according to the Source - Born in Belo Horizonte Study, 2011 to 2013.

\begin{tabular}{|c|c|c|c|}
\hline \multirow{3}{*}{ Trajectory of pregnant women } & \multicolumn{2}{|c|}{ Originating from Belo Horizonte } & \multirow{3}{*}{ P-Value* } \\
\hline & Yes & No & \\
\hline & n (\%) & n (\%) & \\
\hline Time to get to the maternity unit & & & $<0.0001$ \\
\hline Up to 30 minutes & $471(72.7)$ & $158(39.3)$ & \\
\hline 31 to 60 minutes & $124(19.2)$ & $135(33.6)$ & \\
\hline 61 to 120 minutes & $28(4.3)$ & $53(13.2)$ & \\
\hline 121 to 240 minutes & $15(2.3)$ & $27(6.7)$ & \\
\hline$>240$ minutes & $10(1.5)$ & $29(7.2)$ & \\
\hline Type of transportation used & & & $<0.0001$ \\
\hline Private car & $462(68.7)$ & $283(68.2)$ & \\
\hline Bus/Train/Van & $79(11.8)$ & $31(7.5)$ & \\
\hline Taxi & $65(9.7)$ & $11(2.7)$ & \\
\hline Ambulance & $48(7.1)$ & $86(20.7)$ & \\
\hline Walking & $8(1.2)$ & $1(0.2)$ & \\
\hline Other** & $10(1.5)$ & $3(0.7)$ & \\
\hline Childbirth in reference maternity unit & & & $<0.0001$ \\
\hline Yes & $416(80.9)$ & $167(63.7)$ & \\
\hline No & $98(19.1)$ & $95(36.3)$ & \\
\hline Care in another hospital before hospitalization & & & $<0.0001$ \\
\hline Yes & $103(15.3)$ & $143(34.5)$ & \\
\hline No & $569(84.7)$ & $272(65.5)$ & \\
\hline Unfavorable trajectory & & & $<0.0001$ \\
\hline Yes & $185(27.5)$ & $242(58.3)$ & \\
\hline No & $487(72.5)$ & $173(41.7)$ & \\
\hline Total & $672(61.8)$ & 415 (38.2) & \\
\hline
\end{tabular}

* Pearson's chi-square test; ** Police car, motorcycle and city hall car.

Table 2 - Reasons for childbirth outside the reference maternity unit and for non-hospitalization in the first maternity attended - Born in Belo Horizonte Study, 2011 to 2013.

\begin{tabular}{|c|c|c|c|}
\hline \multirow{3}{*}{ Motives } & \multicolumn{2}{|c|}{ Originating from Belo Horizonte } & \multirow{3}{*}{ P-value* } \\
\hline & Yes & No & \\
\hline & n (\%) & n (\%) & \\
\hline Childbirth outside reference maternity unit & & & 0.090 \\
\hline Distance or difficult access & $31(31.7)$ & $29(30.5)$ & \\
\hline Did not like the service & $32(32.7)$ & $21(22.1)$ & \\
\hline Absence of vacancy & $23(23.5)$ & $18(19.0)$ & \\
\hline Lack of obstetrician or pediatrician & $3(3.0)$ & $14(14.7)$ & \\
\hline Emergency & $3(3.0)$ & $4(4.2)$ & \\
\hline Others & $4(4.1)$ & $5(5.3)$ & \\
\hline Not informed & $2(2.0)$ & $4(4.2)$ & \\
\hline Total & $98(100.0)$ & $95(100.0)$ & \\
\hline Non-hospitalization in the previous maternity unit & & & $<0.0001$ \\
\hline Absence of vacancy & $48(46.6)$ & $49(34.2)$ & \\
\hline Not in labor & $30(29.1)$ & $24(16.8)$ & \\
\hline Hospital without on-call doctor & $8(7.8)$ & $44(30.8)$ & \\
\hline Referred due to an at-risk pregnancy & $6(5.8)$ & $15(10.5)$ & \\
\hline Women's choice & $6(5.8)$ & $4(2.8)$ & \\
\hline Others & $5(4.9)$ & $7(4.9)$ & \\
\hline Total & $103(100.0)$ & $143(100.0)$ & \\
\hline
\end{tabular}

* Pearson's chi-square test. 
Table 3 - Prevalence, unadjusted odds ratios and 95\% confidence intervals of an unfavorable trajectory according to sociodemographic characteristics - Born in Belo Horizonte Study, 2011 to 2013.

\begin{tabular}{|c|c|c|c|c|}
\hline \multirow[b]{2}{*}{ Sociodemographic Characteristics } & \multicolumn{2}{|c|}{ Unfavorable trajectory } & \multirow[b]{2}{*}{ P-value* } & \multirow[b]{2}{*}{ OR $(\mathrm{Cl} 95 \%)$} \\
\hline & $\begin{array}{c}\text { Yes } \\
\text { n (\%) }\end{array}$ & $\begin{array}{c}\text { No } \\
\text { n (\%) }\end{array}$ & & \\
\hline Age (years) & & & 0.039 & \\
\hline Up to 19 & $61(48.4)$ & $65(51.6)$ & & $1.47(0.99-2.18)$ \\
\hline $20-34$ & $304(39.0)$ & $475(61.0)$ & & Ref. \\
\hline 35 and older & $62(34.1)$ & $120(65.9)$ & & $0.81(0.57-1.15)$ \\
\hline Education & & & 0.002 & \\
\hline Post-secondary & $51(27.3)$ & $136(72.7)$ & & Ref. \\
\hline High school & $238(40.4)$ & $351(59.6)$ & & $1.81(1.24-2.64)$ \\
\hline Primary school & $136(44.3)$ & $171(55.7)$ & & $2.12(1.41-3.20)$ \\
\hline None & $01(33.3)$ & $02(66.7)$ & & $1.33(0.24-6.16)$ \\
\hline Race/color & & & $<0.0001$ & \\
\hline White & $80(28.2)$ & $204(71.8)$ & & Ref. \\
\hline Dark/Brown/Mulatto & $290(42.7)$ & $389(57.3)$ & & $1.90(1.39-2.60)$ \\
\hline Black & $39(43.3)$ & $51(56.7)$ & & $1.95(1.16-3.28)$ \\
\hline Yellow/oriental & $18(52.9)$ & $16(47.1)$ & & $2.87(1.32-6.26)$ \\
\hline With companion & & & 0.085 & \\
\hline Yes & $300(37.7)$ & $495(62.3)$ & & Ref. \\
\hline No & $127(43.5)$ & $165(56.5)$ & & $1.27(0.96-1.68)$ \\
\hline Socioeconomic Class & & & $<0.0001$ & \\
\hline$A$ or $B$ & $90(28.5)$ & $226(71.5)$ & & Ref. \\
\hline C & $277(43.5)$ & $360(56.5)$ & & $1.93(1.43-2.61)$ \\
\hline $\mathrm{D}$ or $\mathrm{E}$ & $60(44.8)$ & $74(55.2)$ & & $2.04(1.31-3.16)$ \\
\hline
\end{tabular}

* Pearson's chi-square test; OR: Odds Ratio; 95\%CI: 95\% confidence interval.

Table 4 - Prevalence, Unadjusted Odds Ratio and 95\% Confidence Intervals of unfavorable trajectory according to obstetric care characteristics - Born in Belo Horizonte Study, 2011 to 2013.

\begin{tabular}{|c|c|c|c|c|}
\hline \multirow{3}{*}{ Characteristics of Obstetric care } & \multicolumn{2}{|c|}{ Unfavorable trajectory } & \multirow{3}{*}{ P-value* } & \multirow{3}{*}{ OR $(95 \% \mathrm{Cl})$} \\
\hline & Yes & No & & \\
\hline & n (\%) & n (\%) & & \\
\hline Performing prenatal care & & & 0.917 & \\
\hline Yes & $424(39.3)$ & $655(60.7)$ & & Ref. \\
\hline No & $03(37.5)$ & $05(62.5)$ & & $0.93(0.22-3.90)$ \\
\hline Location of the Prenatal care & & & $<0.0001$ & \\
\hline Private & $115(29.7)$ & $272(70.3)$ & & Ref. \\
\hline Public & $284(44.9)$ & $349(55.1)$ & & $1.92(1.46-2.54)$ \\
\hline In both & $25(42.4)$ & $34(57.6)$ & & $1.74(0.96-3.16)$ \\
\hline Number of prenatal care appointments & & & 0.153 & \\
\hline 7 or more appointments & $373(38.6)$ & $594(60.7)$ & & Ref. \\
\hline Up to 6 appointments & $51(45.5)$ & $61(54.5)$ & & $1.33(0.89-1.97)$ \\
\hline Guided regarding the reference maternity unit & & & 0.335 & \\
\hline Yes & $312(40.2)$ & $464(59.8)$ & & Ref. \\
\hline No & $115(37.0)$ & $196(63.0)$ & & $0.87(0.66-1.15)$ \\
\hline
\end{tabular}

* Pearson's chi-square test; OR: Odds Ratio; 95\%CI: 95\% confidence interval.

The prevalence of unfavorable trajectory was higher for births in public maternity hospitals than in private ones (OR 2.58; 95\%CI: 1.95-3.42) (data not shown).

Table 5 presents the chance of some reproductive outcomes when the trajectory was unfavorable. Similar prevalence was observed for the six investigated outcomes regardless of trajectory status, except for vaginal delivery. When the trajectory was unfavorable regarding vaginal delivery, it had a 1.47 chance (95\% CI 1.14-1.88) to occur when compared with those who did not have problems with their trajectory to delivery. 
Table 5 - Prevalence, OR and $95 \% \mathrm{Cl}$ of reproductive outcomes according to unfavorable trajectory for childbirth care - Belo Horizonte, 2011 to 2013.

\begin{tabular}{lccc}
\hline \multicolumn{1}{c}{ Unfavorable trajectory } & $\mathbf{n}(\%)$ & OR & $\mathbf{9 5} \% \mathbf{C I}$ \\
\hline Intercurrences in labor and delivery & $38(8.9)$ & 1.27 & $0.82-1.99$ \\
Yes & $47(7.1)$ & 1 & - \\
No & $260(60.9)$ & 1.47 & $1.14-1.88$ \\
\hline Vaginal birth & $340(51.5)$ & 1 & - \\
Yes & $09(2.1)$ & 1.76 & $0.67-4.58$ \\
No & $08(1.2)$ & 1 & - \\
\hline Fetal/neonatal death & & & 0.85 \\
Yes & $72(18.5)$ & 1 & $0.62-1.18$ \\
No & $119(21.0)$ & 1.19 & - \\
\hline Resuscitation in the delivery room & $33(8.5)$ & 1 & $0.74-1.92$ \\
Yes & $41(7.2)$ & 1.45 & - \\
No & & 1 & $0.99-2.09$ \\
\hline Neonatal ICU admission & $61(14.3)$ & $68(10.3)$ & - \\
Yes & &
\end{tabular}

OR: Odds Ratio; 95\%CI: 95\% confidence interval.

\section{DISCUSSION}

The present study showed that the unfavorable trajectory occurs in at least one in every four births in Belo Horizonte, and in a more pronounced way for pregnant women coming from other municipalities. This prevalence is higher than the findings of other studies which have analyzed pregnant women's trajectories to the maternity hospital, since it included additional information beyond the search for more than one maternity unit. When only considering the commute of pregnant women, the results of the residents in Belo Horizonte are similar to the data from Brazil and the Southeast region, but the situation is more unfavorable for non-residents ${ }^{(7)}$. These findings mainly reflect the fragility and technical and operational lack of preparation of some municipalities in the metropolitan area of Belo Horizonte to provide care for labor and childbirth, even in the absence of gestational risk. Therefore, it is necessary to continue the construction and regulation of pregnant women's health care networks among municipalities through the Pactual and Integrated Program (Programação Pactuada e Integrada $-P P I)^{(15)}$. The establishment of an effective referral and counter-referral flow is fundamental due to the high technological and operational density of the perinatal care network installed in Belo Horizonte, both within the scope of $S U S$ and in supplementary health.

This transfer to the unknown and without guarantees to pregnant woman can generate fear and insecurity ${ }^{(9)}$. It is known that the commute of a pregnant woman in labor in seeking a place for hospitalization is associated with an increase in the risks to the health of the parturient and the newborn ${ }^{(5,11,13)}$. Moreover, a lack of structured service near the pregnant woman's home favors scheduling of elective cesarean sections in order to minimize the need for displacement during labor ${ }^{(17)}$. Thus, it is suggested that the principles of PPI, despite being an instrument established for the SUS Network, should also be applied to organize the care network in supplementary health.

The main reasons for the unfavorable trajectory pointed out by pregnant women, such as lack of places, difficult access, dislike of the service and lack of attendance conditions are similar to previous studies ${ }^{(5,10)}$. It should be noted that a lack of direct access to obstetric care contributes to anxiety and mortality of pregnant women and her family, which interferes with the physiology of childbirth and generates dissatisfaction with the experience. This has been understood as a form of women's rights violation, configuring as institutional violence ${ }^{(11)}$. Public health efforts to address this problem are acknowledged, especially in the Rede Cegonha, but advances are needed to overcome healthcare network fragmentation ${ }^{(10)}$ to build and monitor flows, care and structural processes for ensuring rights which are already assured.

The absence of an obstetric bed in the first service attended as a prevailing cause of searching for another institution evidences an important fragility in health services which leads to precariousness in obstetric care. This may be a reflection of the lack of investment into the construction of new maternity units, as well as for the expansion and adequacy of those existing, resulting in difficulty for the hospital units to receive pregnant women ${ }^{(11)}$. This investment limitation situation affects the smaller maternity units in a particular way, with a lack of teams for providing care; a very present reality in the metropolitan region of Belo Horizonte, causing an overload to the institutions in the capital city. This scenario is also observed elsewhere ${ }^{(18)}$ and demonstrates care inadequacy, contradicts the humanization concept and the rights of women to comprehensive, dignified and quality 
care. It is reaffirmed that the recommendations of RDC36/2008, ratified by the Rede Cegonha $a^{(2)}$,impose the demand for structural reforms in services to meet the propositions of a new care model.

Another important reason found in this study for seeking out a second maternity unit was the fact that the pregnant woman was not in labor. It is known that the physiological processes at the end of gestation provoke anxiety and generate expectation in women, who end up going to the hospital early. Thus, it is essential to counsel pregnant women about the signs and symptoms of labor, which is a quality indicator of prenatal care that can contribute to avoid commuting ${ }^{(4,9-10)}$.

Consistent with the national trend ${ }^{(1,10)}$, high prenatal adherence among pregnant and non-resident pregnant women in Belo Horizonte shows that health programs and policies developed in the area of women's health have positively impacted access to these services ${ }^{(1)}$. However, qualitative advances in prenatal care are required for all actions to be taken, such as counseling on referral maternity units for childbirth care ${ }^{(2-4)}$. In this study, the percentage of women who reported not having received this information in prenatal care was high, especially those who were not residents of Belo Horizonte. These findings are similar to other studies which also confirmed the inadequacy of guidelines on childbirth and breastfeeding in prenatal care ${ }^{(19-20)}$. It should be ensured that the guidelines and explanations given to pregnant women during prenatal care are offered in a way which guarantees the minimum number of consultations, laboratory and imaging tests. This once again reflects the fragility of the service in establishing a flow which guarantees the care continuity initiated in prenatal care.

The presence of a practicing nurse along with a multiprofessional team during prenatal care can be a determining factor in improving the effectiveness of care and the guidelines provided $^{(19)}$. In this sense, the World Health Organization ${ }^{(21)}$ has reinforced the importance of prenatal care as an opportunity to save and improve the lives and health of women through effective communication and support. Thus, the nurse develops screening, diagnosis, and illness prevention and educational measures through the prenatal nursing consultation, which favors adapting pregnant women to the physiological alterations, to recognize risks and adopt measures which provide better results ${ }^{(22-23)}$. Thus, the nurse should provide information on the various aspects of prenatal care both individually and collectively, including operational issues of access and continuity of care at the various levels of the care network. Another possibility is for the nurse to work with the community in the social control of $S U S$ to guarantee health as a right and reduce possible inequities in access to health services.

In this sense, the present study showed a greater chance of unfavorable trajectory for those women in situations of social vulnerability, data which is also shared with other national and international studies ${ }^{(9,11-12)}$. The condition of belonging to a lower social class, being brown/mulatto, black, or yellow/oriental race, and having only a few years of education is a social stigma and a predisposing factor to negating women's citizenship regarding a lack access to health services $^{(12)}$. Still, these women mostly use public health services to perform prenatal care ${ }^{(10)}$, which is related to the result found being that a higher number of unfavorable trajectories for pregnant women who were attended during gestation by the SUS. Women who use private health services have the possibility of scheduling their births to guarantee their vacancy and experience the pre-partum commute to a lesser degree $e^{(10,17)}$.

The fact that the trajectory status of the pregnant women did not interfere in the reproductive outcomes studied, with the exception of the delivery type, can be considered positive, since once they enter services they are able to meet previously unmet needs. This context may be an indicator of the quality of maternity hospitals in Belo Horizonte, a target for more than a decade of public policies aimed at empowering the teams and implementing new care processes. However, the access guarantee to maternity units must be part of the care plan of the pregnant woman, particularly for women in prenatal obstetric risk situations, since in cases of obstetric emergencies, ineffective access constitutes the highest risk for lack of access due to the delay in essential conducts for saving lives ${ }^{(12)}$.

The fact that vaginal delivery has been more frequent among women with an unfavorable trajectory may be related to the type of services to which they are linked, namely the public maternity hospitals. In general, private hospitals in Brazil have a high rate of surgical deliveries ${ }^{(23)}$, and many of these elective surgeries prevent pre-partum commutes ${ }^{(17)}$. In addition, the vaginal delivery outcome should be considered as positive, but which may require improvement, as well as the labor condition which often occurs in transit without adequate comfort and safety conditions.

A possible limitation of this study are other outcomes which were not evaluated such as women's satisfaction with the labor and birth process in an unfavorable trajectory.

\section{CONCLUSION}

The results of this study show that the trajectory taken by women to receive delivery/labor care in the city of Belo Horizonte still occurs unfavorably, especially among residents of the metropolitan region. This scenario highlights weaknesses in the health services network in ensuring timely and qualified access and suggests the need to revise the perinatal care network and the organization of services to meet current demands. These demands are in the political, management and institutional fields, which impact the structural and operational aspects of the health care network, as well as the lives of women and their families in such an importantly singular moment of their lives.

Finally, there is a demand to implement new obstetric care paradigms in seeking to provide the right of access to safe care for women's health and its concept as a priority in the municipalities of the metropolitan area of Belo Horizonte. Political action and effective social control are required to maintain and expand rights, in which nurses have a legacy of historical participation, but which need to be reinforced in the current national context. 


\section{RESUMO}

Objetivo: Analisar a trajetória percorrida pelas gestantes para assistência ao parto em Belo Horizonte e sua relação com os desfechos reprodutivos. Método: Estudo transversal, que utilizou base de dados de uma pesquisa realizada em Belo Horizonte. As variáveis estudadas foram referentes à trajetória da mulher em busca de atendimento para o parto, às suas características sociais, demográficas e assistenciais e aos desfechos reprodutivos. Estimou-se Odds Ratios com seus intervalos de 95\% de confiança para avaliar os fatores associados à trajetória desfavorável e aos desfechos. Resultados: Foram estudados 1.087 casos, dos quais 39,3\% tiveram trajetória desfavorável. A chance de ter trajetória desfavorável foi maior para mulheres não residentes em Belo Horizonte, com menor escolaridade, da raça/cor não branca e que realizaram o pré-natal no serviço público. A prevalência dos desfechos reprodutivos foi semelhante, independentemente do status da trajetória, exceto para parto vaginal. Conclusão: A trajetória desfavorável, ainda elevada, evidencia fragilidades da rede de serviços de saúde para garantir acesso oportuno e qualificado às gestantes. Porém, a assistência recebida nos serviços de saúde supera os riscos da trajetória.

\section{DESCRITORES}

Gestantes; Parto; Acesso aos Serviços de Saúde; Avaliação em Saúde; Enfermagem Obstétrica.

\section{RESUMEN}

Objetivo: Analizar la trayectoria recorrida por las embarazadas para asistencia al parto en Belo Horizonte y su relación con los resultados reproductivos. Método: Estudio transversal, que utilizó la base de datos de una investigación llevada a cabo en Belo Horizonte. Las variables estudiadas fueron referentes a la trayectoria de la mujer en búsqueda de atención al parto, a sus características sociales, demográficas y de asistencia y a los resultados reproductivos. Se estimó Odds Ratios con sus intervalos del 95\% de confianza para evaluar los factores asociados con la trayectoria desfavorable y a los resultados. Resultados: Fueron estudiados 1.087 casos, de los que el 39,3\% tuvieron trayectoria desfavorable. La probabilidad de tener trayectoria desfavorable fue mayor para las mujeres no residentes en Belo Horizonte, con menor escolaridad, de la raza/color no blanco y que realizaron el prenatal en el servicio público. La prevalencia de los resultados reproductivos fue semejante, independientemente del status de la trayectoria, excepto para parto vaginal. Conclusión: La trayectoria desfavorable, todavía elevada, evidencia fragilidades de la red de servicios sanitarios para asegurar el acceso oportuno y calificado a las gestantes. Sin embargo, la asistencia recibida en los servicios sanitarios supera los riesgos de la trayectoria.

\section{DESCRIPTORES}

Mujeres Embarazadas; Parto; Accesibilidad a los Servicios de Salud; Evaluación en Salud; Enfermería Obstétrica.

\section{REFERENCES}

1. Victora CG, Barreto ML, Leal MC, Monteiro CA, Schmidt MI, Paim J, et al. Health conditions and health-policy innovations in Brazil: the way forward. Lancet. 2011;377:2042-2053. DOI: https://doi.org/10.1016/S0140-6736(11)60055-X

2. Brasil. Portaria n. 1.459, 24 de junho de 2011. Institui, no âmbito do Sistema Único de Saúde SUS- a Rede Cegonha [Internet]. Brasília, 25 jun. 2011 [citado 2018 jan. 21]. Disponível em: http://bvsms.saude.gov.br/bvs/saudelegis/gm/2011/prt1459_24_06_2011.html

3. Brasil. Lei n. 11.634 de 27 de dezembro de 2007. Dispõe sobre o direito da gestante ao conhecimento e a vinculação à maternidade onde receberá assistência no âmbito do Sistema Único de Saúde [Internet]. Brasília; 2007 [citado 2018 jan. 21]. Disponível em: http://www. planalto.gov.br/ccivil_03/_Ato2007-2010/2007/Lei/L11634.htm

4. World Health Organization. Standards for Maternal and Neonatal Care. Integrated Management of Pregnancy and Childbirth (IMPAC) [Internet]. Geneva: WHO; 2007 [cited 2018 Jan 21]. Available from: https://www.who.int/maternal_child_adolescent/topics/maternal/ impac/en/

5. Furtado EZL, Gomes KRO, Gama SGN. Acesso à assistência ao parto de adolescentes e jovens na região Nordeste do Brasil. Rev Saúde Pública [Internet]. 2016 [cited 2018 Mar 11];50:23. Disponível em: http://www.scielo.br/pdf/rsp/v50/pt_0034-8910rsp-S1518-87872016050005396.pdf

6. Lansky S, Friche AAL, Silva AAM, Campos D, Bittencourt SDA, Carvalho ML, et al. Pesquisa Nascer no Brasil: perfil da mortalidade neonatal e avaliação da assistência à gestante e ao recém-nascido. Cad Saúde Pública. 2014;30 Supl. 1):192-207. DOI: http://dx.doi. org/10.1590/0102-311X00133213

7. Diniz CSG, Batista LE, Kalckmann LE, Schlithz AOC, Queiroz MR, Carvalho PCA. Sociodemographic inequalities and maternity care of puerperae in Southeastern Brazil, according to skin color: data from the Birth in Brazil national survey (2011-2012). Saúde Soc. [Internet]. 2016 [cited 2018 Mar 28];25(3):561-572. Available from: http://www.scielo.br/pdf/sausoc/v25n3/1984-0470sausoc-25-03-00561.pdf

8. Silva RM, Costa MS, Matsue RY, Sousa GS, Catrib AMF, Vieira LJES. Cartografia do cuidado na saúde da gestante. Cien Saúde Coletiva. 2012;17(3):635-42. DOI: http://dx.doi.org/10.1590/S1413-81232012000300009

9. Serruya SJ. A morte materna no Brasil: razão e sensibilidade. Rev Bras Ginecol Obstet. 2012; 34(12):531-5.

10. Viellas EF, Domingues RMSM, Dias MAB, Gama SGN, Theme-Filha MM, Costa JV, et al. Assistência pré-natal no Brasil. Cad Saúde Pública 2014;30 Supl 1:85-100. DOI: http://dx.doi.org/10.1590/0102-311X00126013

11. Rodrigues DP, Alves VH, Penna LHG, Pereira AV, Branco MBLR, Silva LA. A peregrinação no período reprodutivo: uma violência no campo obstétrico. Esc Anna Nery. 2015;19(4):614-620. DOI: 10.5935/1414-8145.20150082

12. Elmusharaf K, Byrne E, AbuAgla A, AbdelRahim A, Manandhar M, Sondorp E, et al. Patterns and determinants of pathways to reach comprehensive emergency obstetric and neonatal care (CEmONC) in South Sudan: qualitative diagrammatic pathway analysis. BMC Pregnancy Childbirth. 2017;17:278. DOI: https://doi.org/10.1186/s12884-017-1463-9

13. Martins EF, Rezende EM, Souza KV, Lana FCF. Óbitos perinatais investigados: características e falhas na assistência ao parto. Esc Anna Nery [Internet]. 2013 [citado 2018 fev. 18];17(1):38-45. Disponível em: http://www.scielo.br/pdf/ean/v17n1/06.pdf

14. Lansky S. Gestão de qualidade e da integralidade do cuidado em saúde para a mulher e a criança no SUS-BH: a experiência da comissão perinatal. Rev Tempus Actas Saúde Col [Internet]. 2010 [citado 2018 fev. 10];4(4):191-9. Disponível em: http://tempusactas.unb.br/index. php/tempus/article/viewFile/846/809 
15. Brasil. Portaria n. 1097, 22 de maio de 2006. Define o processo da Programação Pactuada e Integrada da Assistência em Saúde seja um processo instituído no âmbito do Sistema Único de Saúde [Internet]. Brasília; 2006 [citado 2018 fev. 10]. Disponível em: http://bvsms. saude.gov.br/bvs/publicacoes/DiretrizesProgPactuadalntegAssistSaude.pdf

16. Vasconcellos MTL, Silva PLN, Pereira APE, Schilithz AOC, Souza Júnior PRB, Szwarcwald CL. Desenho da amostra Nascer no Brasil: pesquisa nacional sobre parto e nascimento. Cad Saúde Pública. 2014;30 Supl.1:S49-58. DOI: http://dx.doi.org/10.1590/0102-311X00176013

17. Copelli FHS, Rocha L, Zampieri MFM, Gregório VRP, Custódio ZAO. Fatores determinantes para a preferência da mulher pela cesariana. Texto Contexto Enferm. 2015;24(2):336-43. DOI: http://dx.doi.org/10.1590/0104-07072015000430014

18. Assunção MF, Soares RC, Serrano I. A superlotação das maternidades em Pernambuco no contexto atual da política de saúde. Serv Soc Rev. 2014;16(2):5-35. DOI: 10.5433/1679-4842.2014v16n2p5.

19. Rodrigues AP, Padoin SMM, Guido LA, Lopes LFD. Fatores do pré-natal e do puerpério que interferem na autoeficácia em amamentação. Esc Anna Nery. 2014;18(2):257-261. DOI: http://dx.doi.org/10.5935/1414-8145.20140037

20. Domingues RMSM, Viellas EF, Dias MAB, Torres JA, Theme-Filha MM, Gama SGN, et al. Adequação da assistência pré-natal segundo as características maternas no Brasil. Rev Panam Salud Pública [Internet]. 2015 [citado 2018 maio 01];37(3):140-7. Disponível em: https:// www.scielosp.org/article/rpsp/2015.v37n3/140-147/

21. World Health Organization. Recommendations on antenatal care for a positive pregnancy experience. Geneva: WHO; 2016 [cited 2018 Feb 10]. Available from: https://www.who.int/reproductivehealth/publications/maternal_perinatal_health/anc-positive-pregnancyexperience/en/

22. Liu L, Coenen A, Tao H, Jansen KR, Jiang AL. Developing a prenatal nursing care International Classification for Nursing Practice catalogue. Int Nurs Rev. 2017;64(3):371-8. DOI: 10.1111/inr.12325

23. Domingues RMSM, Dias MAB, Nakamura-Pereira M, Torres JA, D'Orsi E, Pereira APE, et al. Processo de decisão pelo tipo de parto no brasil: da preferência inicial das mulheres à via de parto final. Cad Saúde Pública [Internet]. 2014 [citado 2018 mar. 15];30 Supl.1:S101-16. Disponível em: http://www.scielo.br/pdf/csp/v30s1/0102-311X-csp-30-s1-0101.pdf 